\title{
KONTRIBUSI KOLAM IKAN "YUMINA BUMINA" SEBAGAI UPAYA PENINGKATAN PENDAPATAN KELUARGA DI DESA JAMPANG BOGOR
}

\section{"YUMINA BUMINA" FISH COLLEGE CONTRIBUTION AS AN EFFORTS TO INCREASE FAMILY INCOME IN JAMPANG BOGOR VILLAGE}

\author{
Rakhmawati Oktavianna $^{1}$, Aditya Pratama ${ }^{2}$, Sulistiyani ${ }^{3}$ \\ ${ }^{1}$ Akuntansi, Universitas Pamulang \\ (r.oktavianna21@gmail.com) \\ ${ }^{2}$ Pendidikan Ekonomi, Universitas Negeri Jakarta \\ (adityapratama@unj.ac.id) \\ ${ }^{3}$ Manajeman, Universitas Pamulang \\ (sulizbimbi@gmail.com)
}

\begin{abstract}
ABSTRAK
Budidaya ikan merupakan sumber mata pencarian terbesar bagi penduduk Desa Jampang. Banyaknya masyarakat sebagai pelaku budidaya ikan air tawar mampu menghasilkan beberapa inovasi dalam penggunaan kolam yang diberi nama kolam YUMINA (sayur dan ikan) BUMINA (buah dan ikan). Adapun tujuan penelitian untuk menganalisis kontribusi kolam ikan "YUMINA BUMINA" sebagai upaya peningkatan pendapatan keluarga di Desa Jampang Bogor. Penelitian ini merupakan penelitian deskriptif kualitatif. Teknik pengumpulan data dilakukan dengan menggunakan teknik observasi, teknik wawancara dan dokumentasi. Responden penelitian ini adalah Para pembudidaya ikan kelompok pintu air di Desa Jampang Bogor. Hasil penelitian menunjukkan bahwa media yang digunakan untuk kolam ikan "YUMINA BUMINA" sangat mudah didapatkan dengan biaya yang sangat murah serta kualitas yang dihasilkan pun terjamin. Untuk pemeliharaannya termasuk lebih sederhana dan mudah. Kesimpulan dari penelitian ini adalah kolam ikan Yumina Bumina memberikan keuntungan ganda bagi para pembudidaya ikan karena dengan sistem ini bisa menghasilkan ikan dan sayuran maupun buah-buahan yang dipelihara dan dapat memberikan keuntungan finansial yang jauh lebih besar dibandingkan dengan cara konvensional.
\end{abstract}

Kata kunci: Peningkatan Pendapatan, Kolam Yumina Bumina

\section{ABSTRACT}

Fish cultivation is the biggest source of livelihood for the residents of Jampang Village. The number of people as freshwater fish aquaculture practitioners is able to produce several innovations in the use of ponds that are named YUMINA ponds (vegetables and fish) BUMINA (fruit and fish). The research objective is to analyze the contribution of the "YUMINA BUMINA" fish pond as an effort to increase family income in the Jampang Village, Bogor. This research is a qualitative descriptive study. Data collection techniques are done using observation techniques, interview techniques and documentation. The respondents of this study were the sluice fish farmers in the Jampang Village, Bogor. The results showed that the media used for fish ponds "YUMINA BUMINA" is very easy to obtain at a very low cost and the quality produced is guaranteed. For maintenance, including simpler and easier. The conclusion of this study is that Yumina Bumina fish ponds provide multiple benefits for fish farmers because this system can produce fish and vegetables and fruits that are maintained and can provide financial benefits far greater than conventional methods.

Keywords: Increased Income, Yumina Bumina Pool

\section{PENDAHULUAN}

Potensi perikanan budidaya kolam di Indonesia memiliki potensi seluas
541.000 ha. Dari jumlah potensi budidaya kolam tersebut baru dimanfaatkan sebesar $24,4 \%$ atau sekitar 131.776 ha. Potensi 
budidaya perairan Indonesia di kolam ini masih ada peluang pengembangan seluas 409.324 ha. Potensi perikanan budidaya tersebut masih harus terus dikembangkan karena menjadi peluang investasi dalam sektor budidaya perikanan di Indonesia baik di tambak maupun kolam. Tujuan Pemberdayaan secara umum merupakan membangun daya dengan mendorong dan memotivasi dan membangkitkan kesadaran akan potensi atau daya yang dimiliki serta adanya upaya untuk mengembangkan kearah yang lebih baik (Hapsari, et al. 2014).

Sektor perikanan budidaya di Indonesia memiliki potensi yang cukup besar dan jika dikelola dengan baik, bisa menjadi motor penggerak perekonomian dan juga mampu menyerap tenaga kerja. Dalam pembangunan ekonomi di Indonesia UKM selalu digambarkan sebagai sektor yang mempunyai peranan penting, karena sebagian besar jumlah penduduknya berpendidikan rendah dan hidup dalam kegiatan usaha kecil baik di sektor tradisional maupun modern (Hapsari, Hakim, \& Soeaidy, 2014). Potensi yang bisa dikembangkan diantaranya perairan air tawar, sungai, danau, kolam, perairan payau (tambak). Kita tidak bisa hanya mengandalkan sektor perikanan tangkap ,meskipun perairan Indonesia sangat luas pastinya akan terus berkurang jika dilakukan penangkapan secara terus menerus.

Budidaya merupakan kegiatan terencana pemeliharaan sumber daya hayati yang dilakukan pada suatu area lahan untuk diambil manfaatatau hasilnya. Budidaya perikanan adalah usaha pemeliharaan dan pengembangbiakan ikan atau organisme air lainnya. Perikanan yang terdapat di sungai, sawah, danau, kolam dan rawa termasuk dalam perikanan budidaya air tawar. Tanah dan air adalah faktor lingkungan yang sangat penting dalam menentukan keberhasilan budidaya ikan air tawar. Jenis tanah yang baik untuk budidaya ikan air tawar adalah jenis tanah liat atau tanah lempung. Tanah jenis ini biasanya baik digunakan untuk pembuatan kolam ikan. Tanah dasar kolam haruslah bermutut baik dan berpengaruh terhadap kualitas air kolam diatasnya dan akan berakibat pada kehidupan atau produksi dari ikan yang di budidayakan dalam kolam tersebut. Air sendiri keberadaannya sangat mutlak diperlukan sebagai media kehidupan ikan. Jumlah dan kualitas air merupakan salah satu faktor yang sangat diperhatikan oleh para pembudidaya ikan karena bisa mengoprimalkan hasil dari budidaya.

Desa Jampang adalah salah satu desa dalam wilayah kecamatan Kemang dan masuk dalam kabupaten Bogor. Desa Jampang dinobatkan sebagai desa penghasil budidaya ikan terbesar di Kabupaten Bogor. Budidaya ikan merupakan sumber mata pencarian terbesar bagi penduduk Desa Jampang. Banyaknya masyarakat sebagai pelaku budidaya ikan air tawar mampu menghasilkan beberapa inovasi dalam penggunaan kolam yang diberi nama kolam Yumina (sayur dan ikan) Bumina (buah dan ikan).

Kolam Yumina Bumina merupakan kolam yang tidak hanya menghasilkan ikan air tawar tetapi juga mampu menghasilkan sayuran dan buah-buahan tertentu dengan memanfaatkan tempat budidaya ikan air tawar. Kolam Yumina Bumina memiliki keunggulan tambahan yang bisa menghasilkan sayur dan buah. Hasil tersebut dapat digunakan sebagai tambahan dalam memenuhi kebutuhan sehari-hari. Dari hasil tersebut maka biaya untuk konsumi keluarga sehari-hari bisa terbantukan. Namun hasil sayur dan buah dari kolam Yumina Bumina memerlukan waktu yang cukup lama sampai menghsilkan buah.

Kolam ikan Yumina dan Bumina, teknologinya dirancang untuk masyarakat yang keterbatasan lahan dan air. Dan dengan teknologi Yumina dan Bumina, pencemaran air akibat limbah budi daya yang berasal dari sisa pakan dan metabolisme ikan (penyebab tingginya $\mathrm{N}$ 
dan $\mathrm{P}$ dalam air) akan diserap dan dimanfaatkan oleh akar tanaman sebagai sumber nutrien. Yumina-Bumina adalah teknik budidaya yang memadukan antara ikan dan sayuran serta buah-buahan. Pada budidaya Yumina-Bumina dikenal empat sistem, yaitu: rakit, aliran atas, aliran bawah serta pasang surut (Supendi et. al, 2015). Sedangkan menurut Nugroho et.al (2018) Yumina-Bumina adalah konsep budidaya yang memadukan pembudidayaan ikan (akuakultur) dan tanaman tanpa media tanah (hidroponik).

Kelebihan dari hasil kolam ikan Yumina Bumina, daging ikan kenyal dan tidak bau lumpur, hasil dari kolam ikan tersebut di Desa Jampang bisa dijual langsung dan bisa juga dijual dalam bentuk lele frozen. Lele frozen ini adalah lele yang sudah di bumbui dan dibekukan bisa bertahan 3 sd 4 bulan. Kelebihan lain dari segi air adalah air yang ada di kolam ikan Yumina Bumina, bisa dipakai lagi dimana air tersebut tidak dibuang. Saat panen, air disedot saja, ikan di ambil cuci dan air tadi masuk lagi bisa ditebar bibit lagi untuk budidaya selanjutnya. Dan bisa digunakan berkali-kali. Kelebihan lainnya dari segi pemeliharaan kolam termasuk mudah, jika medianya (air kolam) bersih dan sehat, sudah terfilter dengan baik maka otomatis ikan sehat dan tidak harus mengobati ikan".

Teknologi Yumina dan Bumina dapat dilakukan dalam berbagai skala, baik skala rumah tangga, maupun skala industri. Akan tetapi bahan dan cara pembuatannya relatif sama yakni membutuhkan kolam, wadah media tanam, media tanam, pompa air dan pemipaan, jenis ikan, jenis tanaman, cara perawatan, waktu budi daya, serta analisis ekonomi. Bahan-bahan yang dibutuhkan dalam budidaya ikan dengan kolam ikan Yumina Bumina sendiri sangatlah terjangkau dan menghemat biaya. Jenis ikan air tawar yang di budidayakan dengan teknologi ini dipilih yang efisien dan nilai ekonomis tinnggi misalnya ikan mas, nila, patin dan lele. Sedangkan untuk tanaman yang cocok dipelihara dengan teknologi ini adalah jenis tanaman semusim yang hidup pada media berkadar air tinggi, seperti cabai terong, kangkung, sawi dan tomat.

Dari penjelasan diatas, maka dari itu penulis sangat tertarik untuk mengambil penelitian mengenai "Kontribusi Kolam Ikan "Yumina Bumina" Sebagai Upaya Peningkatan Pendapatan Keluarga Didesa Jampang Bogor".

Adapun tujuan penelitian ini adalah untuk menganalisis kontribusi kolam ikan "Yumina Bumina" sebagai upaya peningkatan pendapatan keluarga di Desa Jampang Bogor.

\section{METODE}

Jenis penelitian ini adalah kualitatif fenomena dengan menggunakan metode trianggulasi melalui tahapan pengambilan informasi, reduksi informasi, penyajian informasi dan pengambilan kesimpulan. Penelitian ini menggunakan metode kualitatif untuk menggambarkan kondisi riil menganalisi kontribusi kolam Yumina Bumina dalam upaya peningkatan pendapatan masyarakat di Desa Jampang secara mendalam.

Metode analisis data pada penelitian ini memiliki beberapa tahapan yang harus terpenuhi. Tahapan yang pertama adalah tahap observasi, dengan tahapan ini merupakan tahap pengumpulan data dengan menggunakan teknik observasi, teknik wawancara dan dokumentasi. Tahap yang kedua ialah tahap reduksi data,dengan tahap ini sebagai proses seleksi dan pemfokusan data yang ada dilapangan. Tahap ke tiga yaitu tahap penyajian data, tahapan ini merangkai semua informasi yang telah dikumpulkan. Tahap ke empat yaitu tahap penarikan kesimpulan, tahap ini merupakan tahap terakhir daari analisis data. Lokasi penelitian ini berada pada Desa Jampang, Bogor dan sampel penelitian ini adalah Para pembudidaya ikan kelompok pintu air di Desa Jampang Bogor. 
HASIL DAN PEMBAHASAN

Penelitian ini dilakukan di Desa Jampang Bogor yang terkenal dengan budidaya ikan. Rata-rata penduduk desanya berpenghasilan dari membudidaya ikan. Desa Jampang juga terkenal dengan sebutan Mina Politan di mana terkenal dengan budidaya ikan konsumsi maupun ikan hias. Karena itulah peneliti tertarik melakukan penelitian di desa Jampang.

Dalam penelitian ini, penulis mengumpulkan data dengan beragam teknik, di antaranya yaitu teknik wawancara, observasi, dan studi dokumentasi. Wawancara dilakukan untuk mendapatkan data secara langsung dari obyek, begitu juga dengan studi dokumentasi dan observasi.

Ada dua pembahasan dalam penelitian ini yaitu bagaimana proses kerja dari kolam ikan Yumina Bumina. Kolam ikan ini digunakan pada lahan sempit yang dibuat dari bahan sederhana dan tidak permanen dan bisa menghemat air. Dengan biaya yang dikeluarakan relatif murah dan sederhana, namun hasil dari ikan tersebut sangat bernilai ekonomis. Yang kedua adalah hasil dari kolam ikan tersebut, bukan hanya ikan konsumsi yang bisa dipanen namun ada juga hasil buah dan sayuran yang bisa menambah pendapatan.Dalam hal ini akan membahas temuan dari penelitian lapangan yang berkaitan dengan bagaimana kotribusi kolam ikan Yumina Bumina untuk mendapatkan hasil yang baik dan bermanfaat bagi masyarakat didesa Jampang Bogor.

Metode analisis data pada penelitian ini memiliki empat tahapan yang harus terpenuhi. Adapun hasil dari penelitian yang sudah dilakukan adalah:

Observasi tahap awal, di mana peneliti melakukan observasi ke lapangan dengan mewawancarai Bapak Umar Hamzah yang merupakan petugas penyuluh lapangan di Desa Jampang Bogor, untuk lebih mengetahui asal usul dari kolam ikan Yumina Bumina dan bagaimana cara kerja kolam ikan tersebut dan melihat bagaimana kolam ikan tersebut dibuat. Dengan adanya observasi tahap awal, peneliti lebih mengetahui mengenai kolam ikan Yumina Bumina dari mulai cara pembuatannya sampai dengan cara kerja dari kolam ikan tersebut sampai menghasilkan ikan konsumsi seperti lele dan buah-buahan juga sayuran.

Observasi awal penelitian ini, melihat bagaimana kolam Yumina Bumina ini dibuat dengan sistem rakit dengan bahan yang sederhana dan harganya cukup terjangkau. Bahan yang diperlukan adalah bambu yang dibuat sebagai rangka kolam dan kolam dilapisi terpal. Di atas diberikan pot-pot untuk tanaman sayuran dan buahbuahan. Penghubung antara kolam dengan pot tanaman digunakan pipa PVC. Sedangkan pot tanaman diberikan arang sebagai media tanamnya. Kolam ikan Yumina Bumina ini sendiri menggunakan mesin pompa WP 3900 yang cukup hemat listrik.

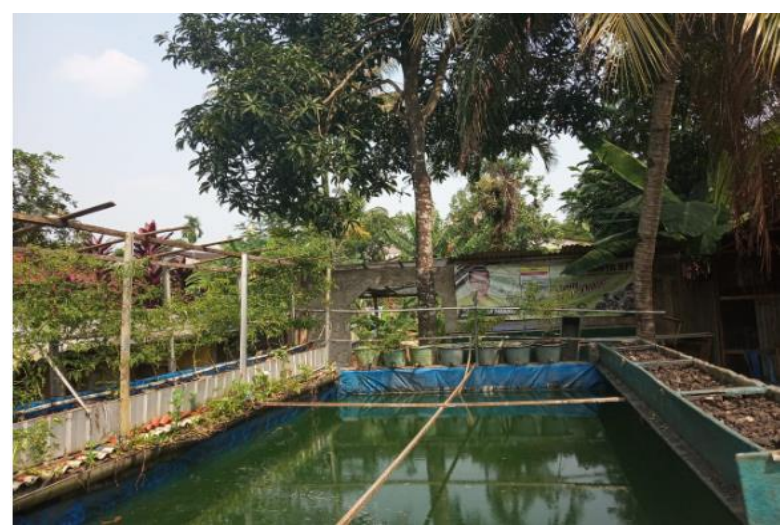

Gambar 1. Kolam Yumina Bumina 
Tahap kedua yang dilakukan oleh peneliti adalah mendatangi narasumber yang merupakan pelaku atau pembudidaya ikan dari kolam ikan Yumina Bumina dan peneliti memilih narasumber yang mampu menghasilkan informasi untuk menjawab permasalahan di dalam penelitian ini. Teknik wawancara dilakukan dengan menentukan narasumber yang representatif terlebih dahulu yang sesuai dengan pertanyaan penelitian.

Tahap ketiga yang dilakukan adalah penyajian data dari informasi yang sudah dikumpulkan dari mulai tahap awal. Adapun informasi yang sudah dikumpulakan adalah Yumina dan Bumina adalah merupakan teknik budidaya ikan dimana pada bagian atas kolam di berikan deretan pot yang berisi tanaman sayuran dan buah-buahan . Sebelumnya kolam ikan Yumina Bumina dikenal dengan istilah akuaponik atau lebih dikenal dengan teknologi budidaya yang mengkombinasikan pemeliharaan ikan dan tanaman.

Yumina sendiri berarti dari $\mathrm{Yu}=$ Sayur dan Mina=Ikan sedangkan Bumina dari $\mathrm{Bu}=\mathrm{Buah}$ dan Mina=Ikan. Kolam ikan yang dibuat sederhana dan diatasnya ditambahkan deretan pot yang dapat ditanami tanaman sayuran maupun buah-buahan. Tanaman diatas pot mendapatkan air dari air kolam ikan, melalui pipa yang saling terhubung antar pot yang secara otomatis mengalir dengan menggunakan bantuan pompa air.

$\begin{array}{crr}\text { Teknologi } & \text { Yumina Bumina } \\ \text { dirancang untuk masyarakat yang }\end{array}$ memiliki keterbatasan lahan dan air, karena kolam ikan Yumina Bumina merupakan teknologi yang hemat lahan dan air. Lahan yang butuhkan tidak perlu luas, cukup dengan ukuran 5 X 2 meter dan air yang di isi sekitar $80 \%$. Untuk jenis ikan yang dipilih adalah ikan konsumsi yaitu ikan lele, ikan mas ataupun ikan nila yang merupakan ikan jenis air tawar.. Dan untuk jenis tanaman bisa di tanam kangkung, selada, sawi dan sebagainya. Untuk tanaman buah biasa dipilih dari jenis tanaman semusim seperti cabai, tomat, terong dan lainnya.

Yumina dan Bumina dapat diterapkan dengan pada skala rumah tangga maupun industri yang memiliki keterbatasan lahan. Penerapan kolam ini sangat di sukai oleh warga masyarakat karena cara perawatan yang mudah, waktu budidaya serta analisis ekonomi. Untuk kolam ada beragam bentuk dan ukuran kolam yang biasa digunakan, disesuaikan dengan luas lahan atau ruang yang ada. Syarat utamanya kolam tidak bocor, dapat dibuat dari tembok, atau tanah berlapis terpal.

Manfaat dari kolam ikan Yumina Bumina adalah dari segi lingkungan di mana bisa mengurangi pencemaran air akibat pembuangan limbah air budidaya ikan dimana terdapat sisa pakan dan kotoran ikan.Dimana sisa pakan dan kotoran ikan tersebut bisa dimanfaatkan sebagai pupuk tanaman yang berada diatas kolam. Pot tanaman sendiri di berikan media arang dimana mampu menyaring racun yang ada di dalam sisa pakan dan kotoran ikan. Sedangkan dari segi ekonomi, metode ini dapat menghemat penggunaan air untuk ikan hingga $700 \%$ dan pemberian pupuk untuk tanaman.

Kolam ikan Yumina Bumina memberikan keuntungan ganda bagi para pembudidaya ikan karena dengan sistem ini bisa menghasilkan ikan dan sayuran maupun buah-buahan yang dipelihara dan dapat memberikan keuntungan finansial yang jauh lebih besar dibandingkan dengan cara konvensional. Cara konvensional adalah memelihara ikan dan tanaman secara terpisah. Media yang digunakan kan pun mudah didapatkan dan biaya yang di keluarkan sangat murah dan kualitas yang dihasilkan terjamin. Untuk pemeliharaannya pun termasuk lebih sederhana dan mudah.

Tahap ke empat yaitu tahap penarikan kesimpulan, tahap ini merupakan tahap terakhir dari analisis data. 


\section{KESIMPULAN DAN SARAN}

Adapun kesimpulan yang didapat dari penelitian ini adalah sebagai berikut:

1. Kolam ikan Yumina Bumina merupakan pengembangan dari kolam ikan yang dibuat oleh kementrian perikanan dan kelautan dan setiap saat sistem yang digunakan di evaluasi oleh para pembudidaya ikan. Teknik budidaya akuaponik ini dikembangkan oleh Balai Penelitian dan Pengembangan Budidaya Air Tawar (BPPBAT) Bogor, Balitbang Kelautan dan Perikanan sejak 2005.

2. Proses kerja dari kolam ikan Yumina Bumina adalah adanya budidaya ikan sekaligus dengan tanaman sayuran dan buah-buahan, dimana air dari kolam di alirkan ke pot tanaman yang berada diatas kolam. Kotoran yang mengalir dapat dijadikan pupuk dan air yang mengalir ke kolam kondisinya lebih bersih.

3. Manfaat dan keunggulan dari kolam ikan Yumina Bumina adalah menghasilkan ikan komsumsi sekaligus dengan dan buah-buahan yang bersifat organik. Selain itu mampu menghemat penggunaan air dan kolam Yumina dan Bumina tidak menimbulkan bau.

4. Dari segi biaya yang di keluarkan untuk pembuatan kolam ikan Yumina Bumina termasuk hemat karena terbuat dari bahan sederhana dan mudah di dapatkan. Penghematan penggunaan air, lahan dan listrik bisa menjadikan kolam ini bisa diterapkan di industri besar selain di rumahan. Namun bila di lihat dari pendapatan yang didapatkan dalam jangka waktu 2 bulan memberikan keuntungan sekitar hampir Rp 2.000.000 jadi apabila kolam tersebut dijadikan usaha sampingan akan mampu meningkatkan pendapatan para pembudidaya ikan di Desa Jampang Bogor.

Adapun saran untuk peneliti selanjutnya yaitu hendaknya melakukan penelitian dengan membandingkan budidaya ikan di beberapa lokasi yang ada di Indonesia.

\section{UCAPAN TERIMA KASIH}

Terimaksih kepada Kementerian Riset, Teknologi dan Pendidikan Tinggi yang telah mengadakan program penelitian, Universitas Pamulang yang telah memfalitasi dalam proses kegitaan program penelitan dan kepada Bapak Umar sebagai narasumber dalam penelitian ini.

\section{DAFTAR PUSTAKA}

Afifuddin dan Beni Ahmad Saebani. 2009 Metodologi Penelitian Kualitatif. cet.1, h.88. Bandung: Pustaka Setia.

Ali, Zaidin. 2010. Pengantar Keperawatan Keluarga. Jakarta: EGC.

Gilarso. 2008. Pengantar Ilmu Ekonomi Mikro. edisi5. Yogyakarta: Kanisius.

Hapsari, Pradnya Paramita, Abdul Hakim, Saleh Soeaidy. 2014. Pengaruh Pertumbuhan Usaha Kecil Menengah (UKM) terhadap Pertumbuhan Ekonomi Daerah (Studi di Pemerintah Kota Batu). Jurnal Wacana Vol. 17, No. 2.

http://kkpnews.kkp.go.id/index.php/potens i-usaha-budidaya-ikan-air-tawar/

Reksoprayitno, Soediyono. 2009. Ekonomi Makro. Yogyakarta: Badan Penerbit Fakultas Ekonomi (BPFE) UGM.

Sugiyono. 2017. Metode Penelitian Kuantitatif, Kualitatif, dan R\&D. Bandung: CV. Alfabeta.

Supendi, Supendi., Muhammad Rizki Maulana dan Samsul Fajar. 2015. Teknik Budidaya Yumina-Bumina 
Sistem Aliran Atas Di Bak Terpal.

Bulletin Teknik Litkayasa Akuakultur.

Vol 13, No 1 Hal 5-9.

Nugroho, tegar assyidiqi, Tibyani dan

Rekyan Regasari Mardi Putri. 2018.

Kontrol Ketinggian Air pada

Budidaya Ikan dan Tanaman

Yumina Bumina Menggunakan

Metode Fuzzy Takagi-Sugeno.

Jurnal Pengembangan Teknologi

Informasi dan Ilmu Komputer. Vol. 2,

No. 7, hlm. 2730-2737. 